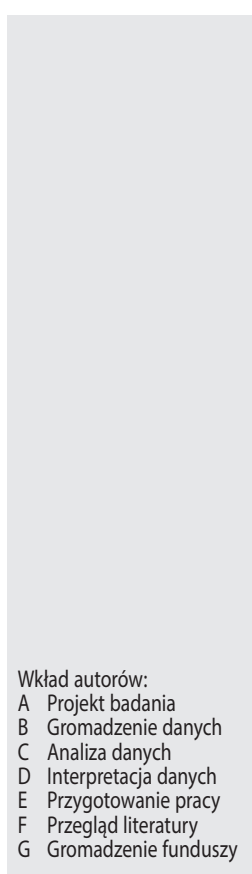

\title{
Program badań przesiewowych słuchu w szkołach podstawowych z terenów wiejskich
}

\section{Hearing screening program in primary schools from rural areas}

\author{
Piotr H. Skarżyński ${ }^{1,2,3, A-B, G}$, Weronika Świerniak ${ }^{1, C-F}$, \\ Małgorzata Karpowicz ${ }^{1, D-E}$, Rita Zdanowicz ${ }^{1, D-E}$, Natalia Czajka ${ }^{1, A-B}$, \\ Henryk Skarżyński ${ }^{4, A, G}$ \\ ${ }^{1}$ Instytut Fizjologii i Patologii Słuchu, Światowe Centrum Słuchu, Zakład Teleaudiologii \\ i Badań Przesiewowych, Warszawa/Kajetany \\ ${ }^{2}$ Warszawski Uniwersytet Medyczny, II Wydział Medyczny, Zakład Niewydolności Serca \\ i Rehabilitacji Kardiologicznej, Warszawa \\ ${ }^{3}$ Instytut Narządów Zmysłów, Kajetany \\ ${ }^{4}$ Instytut Fizjologii i Patologii Słuchu, Światowe Centrum Słuchu, Klinika \\ Otorynolaryngochirurgii, Warszawa/Kajetany
}

\begin{abstract}
Streszczenie
Wstęp: Niezdiagnozowane zaburzenia słuchu ograniczają zdolność dziecka do nauki. Badania przesiewowe słuchu u dzieci w wieku szkolnym pomagają wykryć istotne dla edukacji ubytki słuchu i zapobiegają negatywnemu wpływowi na osiągnięcia w nauce. Celem pracy było oszacowanie rozpowszechnienia zaburzeń słuchu u dzieci w wieku szkolnym z terenów wiejskich w Polsce.

Materiał i metody: Uczestnikami badania było 44323 dzieci (21 169 dziewczynek i 23154 chłopców) w wieku od 6 do 9 lat z 4414 szkół $\mathrm{z}$ terenów wiejskich w Polsce. Wyznaczono próg słyszenia na przewodnictwo powietrzne dla częstotliwości 0,5-8 kHz. Badanie przesiewowe słuchu wykonano przy użyciu Platformy Badań Zmysłów. Ponadto rodzice uczestników badania wypełnili ankietę audiologiczną. Wyniki: Nieprawidłowy wynik badania przesiewowy stwierdzono u 19,5\% badanych dzieci. Większość ubytków słuchu była jednostronna (63,6\%). Tylko $14 \%$ rodziców zauważyło problem ze słuchem u swojego dziecka.

Wnioski: W pracy przedstawiono szacunkowe dane dotyczące przesiewowej audiometrii tonalnej u polskich dzieci z terenów wiejskich. Wykazano, że problemy ze słuchem są powszechne w tej populacji. Badanie ma istotne implikacje dla praktyki klinicznej i polityki zdrowotnej. Wskazuje na potrzebę systematycznego monitorowania stanu słuchu u dzieci oraz zwiększania świadomości rodziców i wychowawców na temat znaczenia ubytków słuchu. Konieczne są dalsze badania prowadzone wśród dzieci z terenów miejskich, aby porównać częstość występowania ubytków słuchu u dzieci z różnych środowisk.
\end{abstract}

Słowa kluczowe: badania przesiewowe słuchu • audiometria tonalna $\bullet$ dzieci w wieku szkolnym • tereny wiejskie

\begin{abstract}
Introduction: Undiagnosed hearing impairments limit a child's ability to learn. Hearing screenings for school-age children help detect educationally significant hearing loss and prevent negative effects on academic achievement. Aim of the study was estimation of the prevalence of hearing disorders in school-aged children from rural areas in Poland.

Material and methods: Participants in the study were 44323 children (21 169 girls and 23154 boys) aged 6 to 9 years from 4414 schools in rural areas of Poland. The air conduction hearing threshold for frequencies $0.5-8 \mathrm{kHz}$ was determined. Hearing screening was performed using the Sensory Testing Platform. In addition, parents completed an audiological questionnaire.

Results: An abnormal screening result was found in $19.5 \%$ of the children tested. Most of the hearing loss was unilateral, i.e. $63.6 \%$. Only $14 \%$ of parents noticed a hearing problem in their child.
\end{abstract}

Adres autora: Piotr H. Skarżyński, Światowe Centrum Słuchu, Instytut Fizjologii i Patologii Słuchu, ul. Mokra 17, 05-830 Nadarzyn, e-mail: p.skarzynski@inz.waw.pl 
Conclusions: The paper presents estimates of tonal audiometry screening in Polish children from rural areas. It was shown that hearing problems are common in this population. The study has important implications for clinical practice and health policy. It indicates the need of systematic monitoring of hearing condition in children and increasing parents' and educators' awareness of importance of hearing loss. Further studies among children from urban areas are needed to compare the prevalence of hearing loss in children from different backgrounds.

Key words: hearing screening • pure-tone audiometry • school-age children • rural areas

Wykaz skrótów

\begin{tabular}{lcc}
\hline Skrót & Rozwinięcie skrótu & Odpowiednik w języku polskim \\
\hline FFPTA & four-frequency pure-tone average & średnia progu słyszenia dla czterech częstotliwości ważnych dla mowy \\
\hline HFPTA HL & high frequency pure-tone average hearing loss & niedosłuch wysokoczęstotliwościowy \\
\hline LFPTA HL & low frequency pure-tone average hearing loss & niedosłuch niskoczęstotliwościowy \\
\hline OME & otitis media with effusion & wysiękowe zapalenie ucha środkowego \\
\hline
\end{tabular}

\section{Wprowadzenie}

Według danych Światowej Organizacji Zdrowia (WHO) szacuje się, że około $34 \mathrm{mln}$ dzieci na całym świecie ma zaburzenia słuchu (ubytek słuchu większy niż $30 \mathrm{~dB}$ w lepszym uchu). Ponadto wśród dzieci poniżej 15. roku życia około $60 \%$ przypadków zaburzeń słuchu można ograniczyć dzięki odpowiednio stosowanej profilaktyce pierwotnej [1]. Wyniki wielu badań pokazują, jak ważne jest wczesne rozpoznawanie dzieci $\mathrm{z}$ zaburzeniami słuchu i wdrażanie odpowiedniego leczenia i rehabilitacji [2]. Badania przesiewowe słuchu u noworodków są obecnie przeprowadzane $\mathrm{w}$ wielu krajach na świecie. Umożliwiają one identyfikację dzieci z wrodzonym ubytkiem słuchu, natomiast inne zaburzenia słuchu mogą się wtedy nie ujawniać lub mogą zostać nabyte w późniejszym okresie dzieciństwa [3]. W Polsce mamy długą tradycję badań przesiewowych słuchu, szczególnie u noworodków. Pierwsze badania słuchu w tej grupie, pod kierownictwem profesora Henryka Skarżyńskiego i docent Marii Góralównej, przeprowadzono w latach 1992-1994. Zaowocowało to opracowaniem programu powszechnych badań przesiewowych słuchu u noworodków, który został wdrożony w Polsce w systemie powszechnej opieki zdrowotnej [4]. Ubytek słuchu jest najbardziej rozpowszechnionym zaburzeniem rozwojowym u dzieci i chociaż poczyniono znaczne postępy w rozpoznawaniu ubytków słuchu po urodzeniu, nadal istnieje ogromna potrzeba prowadzenia systematycznych badań przesiewowych u dzieci w okresie wczesnego dzieciństwa oraz w wieku dojrzewania [5]. Potrzebę stałego monitorowania słuchu u dzieci od najwcześniejszych lat w okresie dzieciństwa podkreślało wielu badaczy i klinicystów [6,7], kładły na to nacisk także liczne organizacje, a m.in.: American Academy of Audiology (AAA) [8], American Speech-Language-Hearing Association (ASHA) [9] oraz European Federation of Audiology Societies (EFAS) [10].

Badania przesiewowe słuchu u dzieci w wieku szkolnym powinny być podstawowym narzędziem do identyfikacji zaburzeń słuchu, które nie zostały rozpoznane podczas badań w okresie noworodkowym lub rozwinęły się w późniejszym czasie. Bez obowiązkowych rutynowych programów badań przesiewowych słuchu w szkołach uczniowie z nabytymi zaburzeniami słuchu mogą pozostać niezidentyfikowani. Skuteczne programy profilaktyczne są kluczowe $\mathrm{w}$ rozpoznawaniu i usuwaniu potencjalnie istotnych barier w uczeniu się $[11,12]$. Odpowiedni do wieku rozwój językowy, poznawczy i społeczny jest związany z umiejętnością prawidłowego słyszenia [13]. Szkolne programy badań przesiewowych mogą pośrednio wpłynąć na poprawę ogólnych wyników w nauce i zmniejszyć niepożądane konsekwencje późnego rozpoznania ubytku słuchu. Są one istotną usługą z zakresu zdrowia publicznego, która ma na celu zmniejszenie globalnego obciążenia chorobami [14]. Istnieją już pewne zalecenia, zgodnie z którymi dzieci poniżej 18. roku życia powinny być poddawane badaniom przesiewowym słuchu w celu wykrycia wrodzonych i/lub nabytych zaburzeń słuchu, które mogą mieć wpływ na zdrowie, rozwój, komunikację lub osiągnięcia edukacyjne [15,16]. W 2015 r. Ministerstwo Zdrowia w Turcji wprowadziło ogólnokrajowy program badań przesiewowych dla uczniów klas pierwszych [17]. W Stanach Zjednoczonych badania przesiewowe słuchu są obowiązkowym szkolnym świadczeniem zdrowotnym, które przeprowadza się, gdy dziecko rozpoczyna naukę w szkole oraz $\mathrm{w}$ regularnych odstępach czasu określonych przez władze danego stanu $[7,11]$.

W Polsce Instytut Fizjologii i Patologii Słuchu (IFPS) nadał priorytet opiece nad dziećmi, w szczególności badaniom przesiewowym, zgodnie z konkluzjami Rady Unii Europejskiej w sprawie wczesnego wykrywania i leczenia zaburzeń komunikacyjnych u dzieci, z wykorzystaniem narzędzi e-zdrowia i innowacyjnych rozwiązań $[18,19]$. Jednym z działań zmierzających do osiągnięcia tego celu była realizacja programu badań przesiewowych wśród dzieci w wieku szkolnym $\mathrm{z}$ terenów wiejskich i małych miast (poniżej 5 tys. mieszkańców) przeprowadzonych we współpracy z Kasą Rolniczego Ubezpieczenia Społecznego (KRUS) [20,21]. Wybór populacji był celowy, ponieważ nadal istnieje zasadnicza potrzeba zmniejszania nierówności w dostępie do świadczeń zdrowotnych na obszarach wiejskich [22,23]. Głównym celem programu była poprawa wczesnej wykrywalności i ocena liczby zaburzeń słuchu u dzieci ze szkół podstawowych $\mathrm{z}$ terenów wiejskich i małych miast w Polsce. W zamierzeniu badania nie były prowadzone w okresie jesiennym, 
czyli w czasie zwiększonej zachorowalności na infekcje górnych dróg oddechowych, w tym infekcje wirusowe. Drugim celem było poszerzenie wiedzy rodziców, dzieci i nauczycieli na temat potencjalnych przyczyn zaburzeń słuchu oraz możliwości profilaktyki, diagnostyki, leczenia i rehabilitacji (w przypadku diagnozy niedosłuchu). Informacje o programie, wraz $\mathrm{z}$ informatorem o profilaktyce i formularzami zgody na badanie, zostały dostarczone do szkół za pośrednictwem jednostek administracji samorządowej (gmin). Nauczyciele rozprowadzali te materiały wśród rodziców podczas cyklicznych spotkań. Współpraca pomiędzy władzami lokalnymi i szkołami przyczyniła się do zwiększenia frekwencji w programie.

\section{Materiał i metody}

Program badań przesiewowych został zrealizowany we wszystkich 16 województwach w Polsce. Od września 2016 r. do czerwca 2017 r. badania przesiewowe słuchu przeprowadzono w 4414 szkołach w 1463 powiatach w Polsce (stanowi to 75,6\% szkół zakwalifikowanych do programu). Liczba zbadanych dzieci w poszczególnych województwach została przedstawiona na rycinie 1. Programem objęto łącznie 44323 dzieci (21 169 dziewczynek i 23154 chłopców) w wieku od 6 do 9 lat. Przed badaniem rodzice lub opiekunowie prawni dziecka wyrażali pisemną zgodę na wykonanie badań oraz wypełniali dobrowolną ankietę dotyczącą świadomości rodzica na temat występowania problemów ze słuchem, przebytych przez dziecko chorób, obecności szumów usznych, nadmiernego hałasu podczas przerw szkolnych oraz ewentualnych wad wymowy. Badanie zostało zaakceptowane przez Komisję Bioetyczną Instytutu Fizjologii i Patologii Słuchu (KB/IFPS:26/8/18) oraz przeprowadzone zgodnie $\mathrm{z}$ postanowieniami deklaracji Helsińskiej.

Badania przesiewowe słuchu przeprowadzono z wykorzystaniem Platformy Badań Zmysłów, która została opracowana przez Instytut Fizjologii i Patologii Słuchu oraz Instytut Narządów Zmysłów (INZ) [22,24]. Platforma wyposażona jest w słuchawki Sennheiser HDA 200, które zapewniają skuteczną izolację akustyczną od hałasu otoczenia. Narzędzie to umożliwia wykonanie przesiewowego badania audiometrycznego na przewodnictwo powietrzne dla każdego ucha oddzielnie w zakresie częstotliwości od 0,5 do $8 \mathrm{kHz}$ i dla poziomów nieprzekraczających $80 \mathrm{~dB}$ HL. Przesiewową audiometrię tonalną przeprowadzili certyfikowani technicy w cichych salach lekcyjnych zgodnie ze zmodyfikowaną procedurą Hughsona i Westlake'a $[25,26]$. Wyniki audiometrycznych badań słuchu były automatycznie gromadzone w centralnej bazie danych SZOK ${ }^{\oplus}$ (System Zintegrowanej Operacji Komunikacyjnej). Dzięki temu systemowi możliwe jest wykonanie analizy statystycznej oraz przekazanie zebranych danych do Instytutu Fizjologii i Patologii, gdzie są oceniane przez specjalistę audiologa lub laryngologa. Zebrane wyniki zostały oznaczone unikalnym identyfikatorem, co gwarantuje pełną ochronę danych osobowych osób badanych zgodnie $\mathrm{z}$ obowiązującym prawem.

Opierając się na wcześniej ustalonych kryteriach, wynik przesiewowego badania audiometrycznego uznawano za nieprawidłowy, jeśli próg słyszenia był powyżej $20 \mathrm{~dB}$ HL na jednej lub kilku częstotliwościach w co najmniej jednym uchu $[23,24]$. Ubytek słuchu zdefiniowano jako średnią progów słyszenia wyższą niż $20 \mathrm{~dB}$ dla co najmniej jednej z wymienionych częstotliwości: istotna dla rozumienia mowy średnia progu słyszenia dla czterech częstotliwości (FFPTA) 0,5, 1, 2 i 4 kHz [27]. Niedosłuch wysokoczęstotliwościowy (HFPTA HL) zdefiniowano jako średni próg słyszenia powyżej $2 \mathrm{kHz}$ (4 i $8 \mathrm{kHz}$ ) [28], a niedosłuch niskoczęstotliwościowy (LFPTA HL) zdefiniowano jako średni próg słyszenia dla 0,5, 1, 2 kHz [29]. Jednostronny ubytek słuchu rozpoznawano, gdy w jednym uchu była norma słuchowa, a w drugim - ubytek słuchu z wartościami progowymi równymi lub większymi niż $25 \mathrm{~dB}$ na jednej lub kilku częstotliwościach [23].

Według obecnie funkcjonującej klasyfikacji WHO dzieci (od urodzenia do 14 roku życia) z ubytkiem słuchu $>30 \mathrm{~dB}$ w uchu lepszym są uznawane za osoby z upośledzeniem słuchu [30]. Taka klasyfikacja budzi wątpliwości. Po pierwsze, zalecany próg dla normalnego słuchu wynoszący $25 \mathrm{~dB}$ nie jest zgodny z kilkoma doniesieniami literaturowymi na temat doświadczeń funkcjonalnych osób z niewielkimi lub łagodnymi ubytkami słuchu ( $<25 \mathrm{~dB}$ poziomu słuchu). Po drugie, definicja upośledzenia słuchu wyłącza wszystkie osoby z jednostronnym ubytkiem słuchu o dowolnym stopniu nasilenia oraz osoby z lekkim obustronnym ubytkiem słuchu, co nie jest zgodne z ICF - Międzynarodową klasyfikacją funkcjonowania, niepełnosprawności i zdrowia (International Classification of Functioning, Disability and Health).

W 2008 r. grupa ekspertów Global Burden Disease (GBD) ds. ubytków słuchu zajęła się tymi problemami i dokonała przeglądu klasyfikacji WHO dotyczącej ubytków słuchu [31]. W efekcie przedstawiono propozycję poprawionej klasyfikacji, w której granicę dla normalnego słuchu obniżono z 25 do $20 \mathrm{~dB}$, wprowadzono oddzielną kategorię dla jednostronnego ubytku słuchu, a sześć kategorii dla obustronnego ubytku słuchu konsekwentnie zróżnicowano w odstępach co $15 \mathrm{~dB}$. W związku z powyższym w niniejszej publikacji zdecydowano się zastosować klasyfikację ICF.

\section{Wyniki}

\section{Przesiewowa audiometria tonalna}

Odsetek pozytywnych wyników badań przesiewowych słuchu wyniósł 19,5\% (8630 uczniów). Odsetek wyników nieprawidłowych był nieco wyższy wśród chłopców - 52,4\% (4522 chłopców) niż wśród dziewcząt - 47,6\% (4108 dziewczynek). Wyniki tego badania wskazują, że szacunkowo $11,4 \%$ dzieci w wieku od 6 do 9 lat, mieszkających na obszarach wiejskich, miało ubytek słuchu w jednym uchu lub obojgu uszach (na podstawie jednej lub więcej średnich wartości progów słyszenia: FFPTA i/lub HFPTA i/lub LFPTA). Częstość występowania ubytku słuchu dla czterech częstotliwości (FFPTA) istotnych dla rozumienia mowy wykazano wśród 6,9\% badanych dzieci (3058 uczniów). Częstość występowania LFPTA HL wykryto wśród 7,7\% badanych dzieci (3412 uczniów), natomiast HFPTA HL wśród 9,1\% (4033 uczniów). U dzieci częściej występował niedosłuch jednostronny niż obustronny. W grupie dzieci z nieprawidłowym wynikiem badania przesiewowego słuchu zaburzenia obustronne stwierdzono u 36,4\% (tj. 3141 uczniów). 


\section{Ankieta audiologiczna}

Wyniki badań audiometrycznych uzupełniono o informacje zawarte w ankietach dotyczących świadomości rodziców na temat zaburzeń słuchu u ich dzieci. Ankiety wypełniło 39928 rodziców, czyli 90,1\% wszystkich rodziców dzieci, które wzięły udział w badaniu. W opisie wyników $\mathrm{w}$ tym podrozdziale uwzględnione zostały tylko wyniki tych dzieci, których rodzice wypełnili ankietę audiologiczną. $\mathrm{Z}$ przeprowadzonego wśród rodziców badania wynika, że $14 \%$ rodziców dzieci, które miały nieprawidłowy wynik badania przesiewowego (7724), zauważyło problemy z percepcją słuchową u swoich dzieci. Okazało się, że także $6,38 \%$ rodziców dzieci, które miały wynik prawidłowy (39 928), uważało, że ich dzieci mają problemy ze słuchem. W większości przypadków, tj. u 63,6\% przebadanych dzieci (5489 uczniów), problem niedosłuchu dotyczył jednego ucha. Wyniki przeprowadzonej ankiety wskazują, że 15,6\% dzieci doświadcza szumów usznych: 7\% doświadczało ich bardzo często lub często, a 93\% rzadko. Spośród dzieci, które uzyskały nieprawidłowy wynik badania przesiewowego słuchu, 30,4\% doświadczało szumów usznych bardzo często lub często, w porównaniu z 23,2\%, które rzadko doświadczały szumów usznych.

Wyniki ankiety pokazują również, że $26,5 \%$ badanych dzieci było wcześniej leczonych z powodu zapaleń uszu, z czego 23\% dzieci miało nieprawidłowy wynik badania. Ponadto na nadmierny hałas w szkole podczas przerw lekcyjnych skarżyło się $14 \%$ badanych dzieci. Interesujące są wyniki dotyczące grupy dzieci z wadą wymowy - okazało się, że aż 71\% rodziców tych dzieci nie zauważyło tego problemu u swojego dziecka.

Przedstawione dane utwierdzają w przekonaniu o szczególnej potrzebie stałego zwiększania dostępności usług medycznych na terenach wiejskich. Wczesne wykrycie ubytku słuchu u ucznia oraz rozpoczęcie leczenia i rehabilitacji umożliwi takiemu dziecku równy start w edukację oraz w konsekwencji pomoże wyeliminować pomoże w wyrównaniu szans edukacyjnych takiemu dziecku, co przełoży się na zmniejszenie potencjalnych niepowodzeń szkolnych.

\section{Dyskusja}

W niniejszym badaniu nieprawidłowy wynik badania przesiewowego miało 8630 uczniów, co stanowi 19,5\% badanej grupy. Wszyscy zostali skierowani do dalszej diagnostyki audiologicznej lub laryngologicznej. Wynik ten jest porównywalny z danymi pochodzącymi z pilotażowych projektów badań przesiewowych słuchu prowadzonych przez Instytut Fizjologii i Patologii Słuchu na różnych kontynentach [5].

W krajach afrykańskich częstość występowania nieprawidłowego wyniku badania przesiewowego wynosi od $18 \%$ do $34 \%$ [32], natomiast w krajach azjatyckich - od $15,9 \%$ do $24,1 \%$ [22,23,33]. Wyniki przytoczonych badań są zbliżone, jednak metodologia (stosowanie różnych protokołów oceny) oraz liczebność próby (badanie populacyjne vs badanie pilotażowe) w wymienionych badaniach znacząco się różniły. Wyniki badań przeprowadzonych w Iranie wykazały, że 10\% dzieci w wieku 7-8 lat może mieć problemy ze słuchem [34]. Mniejsza częstość występowania zaburzeń słuchu może wynikać z zakresu badanych częstotliwości - badania irańskie przeprowadzono w węższym zakresie (od $500 \mathrm{~Hz}$ do 4 tys. Hz). W badaniu przeprowadzonym przez Niskar i wsp. [35] prawie 15\% dzieci w wieku 6-11 lat miało nieprawidłowy wynik badania przesiewowego. Govender i Mars [36] ocenili 146 uszu uczniów szkoły z Republiki Południowej Afryki i stwierdzili ubytek słuchu w 23 uszach u 20 dzieci (16\%). Różnice w częstości występowania mogą być tłumaczone różną liczebnością próby, różnymi protokołami oceny oraz niejednorodnym wiekiem dzieci [37].

Częstość występowania FFPTA w niniejszym badaniu wynosiła $6,9 \%$ i była nieco wyższa niż wyniki badań uzyskane przez Feder i wsp. - 4,7\% [27]. Lin i wsp. [38] przedstawili dane dotyczące zaburzeń słuchu wśród tajwańskich dzieci z terenów wiejskich. Wyniki te wskazują, że w latach 2004-2010 częstość występowania HL wynosiła od 7,88\% do 8,07\% na obszarach wiejskich, a każdego roku obszary wiejskie, w porównaniu z obszarami miejskimi, miały wyższe wskaźniki ogólnej częstości występowania zaburzeń słuchu.

Ponadto częstość występowania ubytków słuchu u dzieci w krajach rozwiniętych jest zwykle niższa niż w krajach rozwijających się [39]. Jak wynika z piśmiennictwa, różnice między obszarami wiejskimi i miejskimi dotyczą nie tylko wyników badań słuchu, lecz także innych aspektów zdrowotnych. Niemal jednogłośnie podkreśla się, że mieszkańcy obszarów wiejskich mają gorszy dostęp zarówno do specjalistów, leków i sprzętu diagnostycznego, jaki i do szkoleń przeznaczonych dla personelu medycznego oraz niższą świadomość zdrowotną [40,41].

W niniejszej pracy LFPTA HL zaobserwowano u 7,7\% badanych dzieci. Wynik ten jest niemal identyczny z wynikiem uzyskanym w badaniach przeprowadzonych na populacji amerykańskiej - 7,1\% [42]. Niskar i wsp. [29] wykazali, że LFPTA HL częściej występował w grupie wiekowej 6-11 lat niż w grupie 12-19 lat (odpowiednio: 7,6\% i 6,6\%). W Kirgistanie wyniki badań przesiewowych słuchu wykazały, że 7,2\% dzieci z nieprawidłowymi wynikami badań przesiewowych miało niskoczęstotliwościowe zaburzenia słuchu [23]. W niektórych przypadkach LFPTA HL może mieć charakter przejściowy. Wtedy, w zależności od specyfiki danego przypadku, skuteczna jest albo interwencja farmakologiczna, albo chirurgiczna. Jedną z najczęstszych przyczyn tego stanu są stany zapalne ucha środkowego $[43,44]$.

HFPTA HL stwierdzono u 9,1\% badanych dzieci. Wynik ten jest wyższy niż w badaniu przeprowadzonym w Stanach Zjednoczonych przez Johnson i wsp. [28], w którym HFPTA HL stwierdzono u 27 na 2867 dzieci, czyli u 7,6\% badanej grupy. Przyczyną niedosłuchu na wysokich częstotliwościach wśród dzieci mogą być: hałas, choroby, infekcje lub czynniki genetyczne [45]. Dzieci z niedosłuchem na wysokich częstotliwościach mogą sprawiać wrażenie nieuważnych lub roztargnionych, ponieważ mają trudności w rozumieniu mowy w hałasie. Podczas przerw pomiędzy lekcjami jest zazwyczaj bardzo głośno i może to powodować problemy społeczne, jeśli dziecko nie słyszy lub źle interpretuje informacje 
w takich warunkach. Przy niedosłuchu wysokoczęstotliwościowym mogą pojawić się również zaburzenia mowy i problemy z artykulacją, dlatego ważne jest, aby otoczyć te dzieci stałym wsparciem w szkole i w środowisku domowym [46].

Jednostronny ubytek słuchu stwierdzono u większości dzieci z pozytywnymi wynikami badań przesiewowych słuchu - 63,6\%. Dane te są zgodne z wcześniejszymi wynikami dotyczącymi lateralności zaburzeń słuchu. Według Kupplera i wsp. [47] oraz Rossa i wsp. [48], jednostronny ubytek słuchu jest najbardziej rozpowszechnioną formą ubytku słuchu, występuje u około $77 \%$ dzieci w wieku szkolnym, u których wynik badania przesiewowego słuchu był nieprawidłowy. Również Niskar i wsp. [29] stwierdzili, że prawie $82 \%$ dzieci z nieprawidłowym wynikiem badań przesiewowych w USA ma jednostronny niedosłuch, a Skarżyński i wsp. [22] podali, że w Tadżykistanie jednostronne zaburzenia słuchu występują u 50\% wszystkich dzieci z ubytkiem słuchu. Dane dotyczące irańskiej populacji dziecięcej [36] wskazują, że zaburzenia słuchu tylko po jednej stronie stanowią 75\% wszystkich zgłaszanych ubytków słuchu. Warto podkreślić, że jednostronny ubytek słuchu jest trudny do rozpoznania przez dzieci, rodziców i nauczycieli, co jeszcze bardziej uwypukla rolę programów przesiewowych w jego skutecznym wykrywaniu. Obuuszne słyszenie zapewnia lepszą percepcję mowy, lepszą lokalizację dźwięków, zwiększoną percepcję głośności dzięki obuusznej sumacji oraz ogólną poprawę słyszenia zarówno w hałaśliwym, jak i cichym otoczeniu [24].

Zgodnie z danymi badania ankietowego 15,6\% rodziców stwierdziło, że ich dzieci doświadczają szumów usznych. W przeglądzie przeprowadzonym przez Rosinga i wsp. [49] stwierdzono, że szacunkowa częstość występowania szumów usznych w ogólnej populacji pediatrycznej wynosi od 4,7\% do 46\%. Z badań autorstwa Raj-Koziak i wsp. [50] wynika, że dzieci rzadko spontanicznie skarżą się na szumy uszne, a ich rodzice nie są świadomi, że doświadczają one tej dolegliwości. Szumy uszne mogą być niezależnym objawem, ale mogą też poprzedzać pełnoobjawowy ubytek słuchu, dlatego należy zwracać na nie uwagę podczas rutynowych badań pediatrycznych [51].

Badanie przeprowadzone przez Harmesa i wsp. [52] wykazało, że u około $80 \%$ dzieci w okresie dzieciństwa występuje co najmniej jeden epizod ostrego zapalenia ucha środkowego (OZUŚ), a 80-90\% będzie miało co najmniej jeden epizod zapalenia ucha środkowego $\mathrm{z}$ wysiękiem (OME) przed osiągnięciem wieku szkolnego. W niniejszym badaniu 29,5\% rodziców zadeklarowało, że ich dziecko było leczone z powodu zapalenia ucha środkowego. Chociaż większość zakażeń ma podłoże bakteryjne, OME może być powikłaniem dysfunkcji trąbki Eustachiusza związanej z ostrą infekcją wirusową górnych dróg oddechowych [53]. Zapalenie ucha środkowego jest jedną z najczęstszych przyczyn przejściowej utraty słuchu [44]. Podczas takich epizodów należy podjąć, zarówno w domu, jak i w szkole, działania profilaktyczne takie jak m.in. zasugerowanie nauczycielom, aby dziecko przesadzili bliżej tablicy oraz aby rozmawiali z nim twarzą w twarz. Rodzice muszą zrozumieć, że z powodu obecności płynu w uchu środkowym dziecko nie będzie dobrze słyszeć i że zaburzenia zachowania, które w tym okresie mogą wystąpić u dziecka, najczęściej wynikają z jego frustracji. Ważnym przesłaniem przeprowadzonych badań jest to, że należy poszukiwać skutecznych sposobów edukowania i zwiększania świadomości zarówno rodziców, jak i nauczycieli na temat objawów zaburzeń słuchu [54].

\section{Wnioski}

Program badań przesiewowych powinien spełniać cel, jakim jest zapewnienie efektywnej kosztowo metody identyfikacji osób wymagających dalszej oceny medycznej i/lub leczenia. Aby osiągnąć ten cel w sposób wiarygodny, należy z jednej strony zachować wymagane standardy, a z drugiej - unikać prób przeprowadzania oceny diagnostycznej. Tylko szczegółowa diagnostyka umożliwia bowiem postawienie diagnozy. Metodyka niniejszego badania zawierała jedynie audiometrię tonalną na przewodnictwo powietrzne. Wszystkie dzieci z wynikiem nieprawidłowym kierowane były do dalszej diagnostyki otorynolaryngologicznej i audiologicznej. Tylko szczegółowa diagnostyka umożliwia postawienie diagnozy oraz ustalenie przyczyny i rodzaju niedosłuchu. Rodzice mieli dowolność w wyborze specjalistycznych poradni i ośrodków zdrowia, w których przeprowadza się taką diagnostykę.

Istnieje wiele barier, które uniemożliwiają dzieciom skorzystanie z pomocy medycznej, jak np. brak możliwości dojazdu do ośrodków medycznych, brak możliwości wzięcia wolnego dnia w pracy przez rodziców oraz brak środków finansowych w rodzinie lub brak świadomości rodziców na temat problemów ze słuchem. Między innymi z uwagi na te czynniki należy rozważyć, czy udział dzieci w wieku szkolnym w badaniach przesiewowych słuchu powinien być obowiązkowy lub przynajmniej zalecany przez centralne lub lokalne władze oświatowe. Pierwszym krokiem byłoby powołanie koordynatora projektu na szczeblu powiatowym. Powinna to być osoba, która współpracowałaby ze społecznością lokalną i koordynowała przepływ informacji, zasobów i usług programowych. W przypadku dużych szkół przydatne byłoby również powołanie koordynatora szkolnego (np. pielęgniarki szkolnej, logopedy, doradcy szkolnego), który byłby w stanie nawiązać kontakt z dziećmi i ich rodzicami. Niedrogie badania przesiewowe słuchu przyczyniłyby się do zwiększenia wykrywalności zaburzeń słuchu wśród dzieci, a w konsekwencji do wdrożenia odpowiedniego leczenia i rehabilitacji dzieci z terenów wiejskich. Dzięki odpowiedniemu sprzętowi i protokołom badań oraz ścisłej współpracy z dobrze wyszkolonym personelem szkoły (np. pielęgniarkami szkolnymi) możliwe jest przeprowadzenie badań przesiewowych słuchu wśród dzieci w wieku szkolnym. Zaproponowany protokół i platforma do badania narządów zmysłów zastosowane w niniejszym badaniu są efektywnymi kosztowo i bezpiecznymi narzędziami, wydają się zatem skuteczne w identyfikacji przypadków poporodowego ubytku słuchu, co umożliwia wczesną interwencję.

Publikacja powstała w związku z realizacją projektu pn. System Zintegrowanej Operacji Komunikacyjnej - „SZOK” dotyczącego utrzymania aparatury naukowo-badawczej / stanowiska badawczego, dofinansowanego na podstawie decyzji nr 8/E-523/SPUB-I/SN/2020 przez Ministerstwo Nauki i Szkolnictwa Wyższego. 


\section{Piśmiennictwo}

1. World Health Organization. Global costs of unaddressed hearing loss and cost-effectiveness of interventions: a WHO report, 2017; https://apps.who.int/iris/handle/10665/254659 [dostęp: 2.08.2021]

2. Olusanya BO. Highlights of the new WHO Report on Newborn and Infant Hearing Screening and implications for developing countries. Int J Pediatr Otorhinolaryngol, 2011; 75(6): 745-8.

3. Włodarczyk EA, Szkiełkowska A, Skarżyński H, Miaśkiewicz B, Skarżyński PH. Reference values for psychoacoustic tests on Polish school children 7-10 years old. PLoS ONE, 2019; 14(8).

4. Mueller-Malesińska M, Skarżyński H, Ołtarzewski M, Szymborski J, Ratyńska J. Project of the countrywide data collecting system for neonatal hearing screening programme in Poland. Scand Audiol Suppl, 2001; (52): 197-8.

5. Skarżyński PH, Ludwikowski M. Hearing Screening around the World. IntechOpen, 2018; https://www.intechopen.com/chapters/59332 [dostęp: 30.07.2021].

6. Watkin PM, Baldwin M. Identifying deafness in early childhood: requirements after the newborn hearing screen. Arch Dis Child, 2011; 96(1): 62-6.

7. Hurley A, Willis M, Guidry M, Bode D, Corneille ML, Mills S. A Program Review of Head Start and Elementary School Hearing Screenings. Lang Speech Hear Serv Sch, 2020; 51(2): 345-52.

8. ASHA. School-Age Hearing Screening, https://www.asha.org/advocacy/state/school-age-hearing-screening/ [dostęp: 4.08.2021].

9. Childhood Hearing Screening: Key Issues, https://www2.asha. org/PRPSpecificTopic.aspx?folderid=8589935406\&section $=$ Key_ Issues [dostęp: 15.07.2021].

10. Skarżyński PH. European Consensus statement on hearing, vision, and speech screening in pre-school and school-age children, 2011; https://www.academia.edu/18307062/European_Consensus_statement_on_hearing_vision_and_speech_screening_in_ pre-school_and_school-age_children [dostęp: 27.07.2021].

11. Dodd-Murphy J, Murphy W, Bess FH. Accuracy of school screenings in the identification of minimal sensorineural hearing loss. Am J Audiol, 2014; 23(4): 365-73.

12. Tamanini D, Ramos N, Dutra LV, Bassanesi HJC, Tamanini D, Ramos N i wsp. School-age hearing screening: identification of hearing impairments in first grade students. Rev CEFAC, 2015; 17(5): 1403-14

13. White EJ, Hutka SA, Williams LJ, Moreno S. Learning, neural plasticity and sensitive periods: implications for language acquisition, music training and transfer across the lifespan. Front Syst Neurosci, 2013; 7: 90.

14. Cloete T-L, Wilson WJ, Petersen L, Kathard H. Identifying a context-effective school hearing screening test: An emic/etic framework. Int J Audiol, 2015; 54(9): 605-12.

15. Jedrzejczak WW, Pilka E, Skarzynski PH, Skarzynski H. Contralateral suppression of otoacoustic emissions in pre-school children. Int J Pediatr Otorhinolaryngol, 2020; 132: 109915.

16. Swanepoel D, Störbeck C, Friedland P. Early hearing detection and intervention in South Africa. Int J Pediatr Otorhinolaryngol, 2009; 73(6): 783-6.

17. Kaplama ME, Ak S. The results of hearing screening in refugee school children living in Şanliurfa /Turkey and the related risk factors. Int J Pediatr Otorhinolaryngol, 2020; 134: 110041.

18. Skarżyński H, Piotrowska A. Screening for pre-school and school-age hearing problems: European Consensus Statement. Int J Pediatr Otorhinolaryngol, 2012; 76(1): 120-1.

19. Skarżyński H, Piotrowska A. Prevention of communication disorders--screening pre-school and school-age children for problems with hearing, vision and speech: European Consensus Statement. Med Sci Monit Int Med J Exp Clin Res, 2012; 18(4): SR17-21.
20. Skarzynski PH, Kochanek K, Skarzynski H, Senderski A, Wysocki J, Szkielkowska A i wsp. Hearing Screening Program in School-Age Children in Western Poland, J Int Adv Otol, 2011; 7: 194-200.

21. Skarzynski H, Kochanek K, Senderski A, Skarzynski PH, Ludwikowski M, Kopaczewski M i wsp. Organization of the hearing screening examinations in Polish schools in rural areas and small towns. Cochlear Implants Int, 2010; 11 (Suppl. 1): 143-7.

22. Skarzyński PH, Świerniak W, Piłka A, Skarżynska MB, Włodarczyk AW, Kholmatov D i wsp. A Hearing Screening Program for Children in Primary Schools in Tajikistan: A Telemedicine Model. Med Sci Monit Int Med J Exp Clin Res, 2016; 22: 2424-30.

23. Skarżyński PH, Świerniak W, Gos E, Pierzyńska I, Walkowiak A, Cywka KB i wsp. Results of hearing screening of school-age children in Bishkek, Kyrgyzstan. Prim Health Care Res Dev, 2020; 21: e18.

24. Skarżyński H, Gos E, Świerniak W, Skarżyński PH. Prevalence of hearing loss among polish school-age children from rural areas - Results of hearing screening program in the sample of 67416 children. Int J Pediatr Otorhinolaryngol, 2019; 128: 109676.

25. Śliwa L, Hatzopoulos S, Kochanek K, Piłka A, Senderski A, Skarżyński PH. A comparison of audiometric and objective methods in hearing screening of school children. A preliminary study. Int J Pediatr Otorhinolaryngol, 2011; 75(4): 483-8.

26. Tyler RS, Wood EJ. A comparison of manual methods for measuring hearing levels. Audiol Off Organ Int Soc Audiol, 1980; 19(4): 316-29.

27. Feder KP, Michaud D, McNamee J, Fitzpatrick E, Ramage-Morin P, Beauregard Y. Prevalence of Hearing Loss Among a Representative Sample of Canadian Children and Adolescents, 3 to 19 Years of Age. Ear Hear, 2017; 38(1): 7.

28. Johnson K, Tabangin M, Meinzen-Derr J, Cohen AP, Greinwald JH. High-frequency sensorineural hearing loss in children. Laryngoscope, 2016; 126(5): 1236-40.

29. Niskar AS, Kieszak SM, Holmes A, Esteban E, Rubin C, Brody DJ. Prevalence of hearing loss among children 6 to 19 years of age. The Third National Health and Nutrition Examination Survey. JAMA, 1998; 279(14): 1071-5.

30. Olusanya BO, Davis AC, Hoffman HJ. Hearing loss grades and the International classification of functioning, disability and health. Bull World Health Organ, 2019; 97(10): 725-8.

31. Stevens G, Flaxman S, Brunskill E, Mascarenhas M, Mathers CD, Finucane $\mathrm{M}$ i wsp. Global and regional hearing impairment prevalence: an analysis of 42 studies in 29 countries. Eur J Public Health, 2013; 23(1): 146-52.

32. Skarżyński PH, Świerniak W, Piłka A, Ludwikowski M, Gos E, Skarżyńska MB i wsp. Pilotażowe przesiewowe badania słuchu $\mathrm{u}$ dzieci w wieku szkolnym $\mathrm{z}$ różnych krajów w Afryce. Now Audiofonol, 2018; 7(4): 29-34.

33. Skarzynski PH, Cyran O, Świerniak W, Wołujewicz K, Barylyak R, Skarżyński H. Pilot hearing screening in schoolchildren from Armenia, Russia, Kyrgyzstan, and Azerbaijan. J Hear Sci, 2020; 10(2): 35-9.

34. Sarafraz M, Ahmadi K. A practical screening model for hearing loss in Iranian school-aged children. World J Pediatr WJP, 2009; 5(1): 46-50.

35. Niskar AS, Kieszak SM, Holmes AE, Esteban E, Rubin C, Brody DJ. Estimated prevalence of noise-induced hearing threshold shifts among children 6 to 19 years of age: the Third National Health and Nutrition Examination Survey, 1988-1994, United States. Pediatrics, 2001; 108(1): 40-3. 
36. Govender S, Latiff N, Asmal N, Ramsaroop S, Mbele T. Evaluating the Outcomes of a Hearing Screening Service for Grade One Learners in Urban Areas at Durban, South Africa. J Public Health Afr, 2015; 6(1).

37. Piotrowska A, Zapert A, Tarczyński K, Kochanek K. Analiza wybranych parametrów audiometrycznych przesiewowych badań słuchu wykonywanych w szkołach. Now Audiofonol, 2014; 3(4): 9-13.

38. Lin C-Y, Tseng Y, Guo H, Lai D. Prevalence of childhood hearing impairment of different severities in urban and rural areas: a nationwide population-based study in Taiwan. BMJ Open, 2018; 8(3).

39. Mahomed-Asmail F, Swanepoel DW, Eikelboom RH. Hearing loss in urban South African school children (grade 1 to 3). Int J Pediatr Otorhinolaryngol, 2016; 84: 27-31.

40. Fortnum H, Ukoumunne OC, Hyde C, Taylor RS, Ozolins M, Errington S i wsp. A programme of studies including assessment of diagnostic accuracy of school hearing screening tests and a cost-effectiveness model of school entry hearing screening programmes. Health Technol Assess, 2016; 20(36): 1-178.

41. Pilka E, Jedrzejczak WW, Kochanek K, Pastucha M, Skarzynski H. Assessment of the Hearing Status of School-Age Children from Rural and Urban Areas of Mid-Eastern Poland. Int J Environ Res Public Health, 2021; 18(8): 4299.

42. Bess FH. The minimally hearing-impaired child. Ear Hear, 1985; 6(1): 43-7.

43. Minovi A, Dazert S. Diseases of the middle ear in childhood. GMS Curr Top Otorhinolaryngol Head Neck Surg, 2014; 13: Doc11.

44. Herzog C, Homøe P, Koch A, Niclasen J, Dammeyer J, Lous J i wsp. Effects of early childhood otitis media and ventilation tubes on psychosocial wellbeing - A prospective cohort study within the Danish National Birth Cohort. Int J Pediatr Otorhinolaryngol, 2020; 133: 109961.
45. Wilcox SA, Saunders K, Osborn AH, Arnold A, Wunderlich J, Kelly $\mathrm{T}$ i wsp. High frequency hearing loss correlated with mutations in the GJB2 gene. Hum Genet, 2000; 106(4): 399-405.

46. Stelmachowicz PG, Pittman AL, Hoover BM, Lewis DE, Moeller MP. The importance of high-frequency audibility in the speech and language development of children with hearing loss. Arch Otolaryngol Head Neck Surg, 2004; 130(5): 556-62.

47. Kuppler K, Lewis M, Evans AK. A review of unilateral hearing loss and academic performance: is it time to reassess traditional dogmata? Int J Pediatr Otorhinolaryngol, 2013; 77(5): 617-22.

48. Ross DS, Holstrum WJ, Gaffney M, Green D, Oyler RF, Gravel JS. Hearing Screening and Diagnostic Evaluation of Children With Unilateral and Mild Bilateral Hearing Loss. Trends Amplif, 2008; 12(1): 27-34.

49. Rosing SN, Schmidt JH, Wedderkopp N, Baguley DM. Prevalence of tinnitus and hyperacusis in children and adolescents: a systematic review. BMJ Open, 2016; 6(6).

50. Raj-Koziak D, Gos E, Swierniak W, Skarzynski H, Skarzynski PH. Prevalence of tinnitus in a sample of 43,064 children in Warsaw, Poland. Int J Audiol, 2020 (Online ahead of print).

51. Raj-Koziak D, Skarżyński H, Kochanek K, Fabijańska A. Czynniki ryzyka szumów usznych u dzieci w wieku 7 lat. Otolaryngol Pol, 2013; 12(1): 42-47.

52. Harmes K, Blackwood RA, Burrows H, Cooke JM, Harrison RV, Passamani P. Otitis Media: Diagnosis and Treatment. Am Fam Physician, 2013; 88(7): 435-40.

53. Czech D, Malicka M, Kott E, Zakrzewska A. Ocena występowania zaburzeń artykulacyjnych u dzieci z nawracającymi infekcjami górnych dróg oddechowych. Otorynolaryngologia - Przegląd kliniczny, 2011; 10(3): 116-20.

54. Gunasekera H, Morris PS, McIntyre P, Craig JC. Management of children with otitis media: A summary of evidence from recent systematic reviews. J Paediatr Child Health, 2009; 45(10): 554-63. 